\title{
Effects of dietary concentrate level on ruminal fermentation and microbial growth efficiency in dual flow continuous culture*
}

\author{
L. Lu ${ }^{1}$, Z.G. Xia ${ }^{2,3}$, M. Lin ${ }^{3}$, X.X. Wang ${ }^{1}$ and Q.X. Meng ${ }^{3,4}$ \\ ${ }^{1}$ Department of Animal Science, Beijing University of Agriculture \\ Beijing 102206, P.R. China \\ ${ }^{2}$ Department of Certification, China Green Food Development Centre \\ Beijing 100081, P.R. China \\ ${ }^{3}$ College of Animal Science \& Technology, China Agricultural University \\ Beijing 100094, P.R. China
}

\begin{abstract}
A dual-flow continuous culture system was used to study the effect of dietary concentrate levels $(0,20,40,60,80,100 \%)$ on rumen fermentation characteristics and microbial growth efficiency. Dilution rates of solid and liquor fractions were set at $0.04 / \mathrm{h}$ and $0.08 / \mathrm{h}$, respectively. The results showed that increasing concentrate level resulted in increased digestibilities of DM and OM, but in decreased digestibilities of NDF and ADF. Also, as the concentrate level increased, there was a decrease in ruminal $\mathrm{pH}$, ammonia concentration and an increased total VFA production. Increasing dietary concentrate level, the molar proportion of propionate linearly increased, but that of acetate decreased. As dietary concentrate level increased, daily microbial $\mathrm{N}$ production (DMNP) and microbial growth efficiency (MOEFF) increased. The maximum DMNP and MOEFF were achieved at $80 \%$ dietary concentrate level.
\end{abstract}

KEY WORDS: continuous culture, rumen microbial growth efficiency, concentrate level

\section{INTRODUCTION}

Since rumen microbes are an important source of protein for the ruminant and since microbial growth rates can affect amino acid availability to the animal, it is important to study factors that may influence microbial protein synthesis and to

\footnotetext{
* Supported by National Outstanding Young Scientist Foundation, Grant No. 30125033, and National Natural Science Foundation of China, Grant No. 30270944 and 39670542

${ }^{4}$ Corresponding author: e-mail: qxmeng@cau.edu.cn
} 
optimize the yield of protein. The factors that affect microbial protein synthesis include: dietary concentrate level and source of nitrogen and carbohydrates, rumen dilution, rumen turnover rate, dietary sulphur and feeding frequency, etc. (Meng et al., 1999). Some studies indicated that the rumen microbial growth efficiency [g of microbial N/kg of digested organic matter (DOM)] reduced with high dietary concentrate levels. However, the conclusions are still not consistent.

The purposes of this study were to determine the effect of dietary concentrate level on rumen fermentation characteristics and microbial growth efficiency in continuous culture and to find out an appropriate dietary concentrate level at which the maximum ruminal microbial efficiency and daily microbial $\mathrm{N}$ yield were achieved.

\section{MATERIAL AND METHODS}

The dual-flow continuous culture system (Model-III, China Patent No. ZL 01 104466.7) was designed and used in this study. The fermenter was equipped with an effluent outlet at a height to provide a liquid fermenter volume of 1760 $\mathrm{ml}$. A mineral buffer solution (Stern and Hoover, 1990) with urea and L-cysteine hydrochloride added at 0.5 and $0.25 \mathrm{~g} / 1$ was infused into the fermenters. Liquid and solid dilution rates were adjusted by buffer infusion and pump removal and maintained at 0.04 and $0.08 / \mathrm{h}$, respectively. Infusing continuously with $\mathrm{CO}_{2}(40$ $\mathrm{ml} / \mathrm{min}$ ) and temperature was maintained at $39^{\circ} \mathrm{C}$.

Six treatment diets (Table 1) were formulated and assigned to one of 12 fermenters with 2 fermenters per diet.

Ruminal fluid was collected from two cannulated cattle was added to the fermenters by hands in equal portions at 6-h intervals. Fermenters were supplied with a total of $80 \mathrm{~g}$ DM of each diet over 24-h period. Experimental periods included 7 -d adaptation period followed by 3 -d sampling period. The continuous culture was run two times on different days.

The total effluent collected and recorded for volume over the sampling days. Bacterial samples were obtained from entire fermenter contents. The contents were stained through two layers of cheesecloth and centrifuged at $500 \mathrm{~g}$ for $10 \mathrm{~min}$ to removal feed particles and protozoa, the supernatant fluid was centrifuged at 20,000 $g$ for $20 \mathrm{~min}$ and washing were freeze-dried in a lyophilizer $\left(10^{\circ} \mathrm{C}\right.$, shelf; Model 44C2-A, Beijing Boyikang Instrument Co., Ltd., Beijing) and ground through a 1$\mathrm{mm}$ screen for further chemical analysis. The subsamples of undigested diets and isolated rumen microorganisms were analysed for DM, OM and $\mathrm{N}$ in freeze dried digesta based on the method of AOAC (1984). The $\mathrm{pH}$ of fermenter content was determined by placing a glass-electrode $\mathrm{pH}$ meter into the fermenter every day. Ammonia-N was determined with the hypochlorite-phenol procedure (Broderick and Kang, 1980). Volatile fatty acid concentrations were determined using GC 
according to the procedure by Grigsby et al. (1993). NDF and ADF were determined according to Van Soest et al. (1991). Purines in bacteria were determined according the procedure of Zinn and Owens (1986). Microbial $\mathrm{N}$ of effluent residues was calculated from the RNA-to-N ratio of isolated microorganisms in conjunction with RNA content of the effluent residues. Microbial efficiency was expressed as grams of microbial $\mathrm{N}$ per kilogram of OM truly digested. Digestibilities were calculated as described by Crawford et al. (1980), except that corrections were made for volatilization of the buffer salt that occurred during freeze-drying. True OM digestibility was calculated as apparently digested OM plus bacterial OM.

Table 1. Ingredient and chemical composition of substrate diets, \% of DM

\begin{tabular}{|c|c|c|c|c|c|c|}
\hline \multirow{2}{*}{ Item } & \multicolumn{6}{|c|}{ Dietary concentrate level, $\%$} \\
\hline & 0 & 20 & 40 & 60 & 80 & 100 \\
\hline \multicolumn{7}{|l|}{ Ingredients, \% } \\
\hline ground maize grains & 0 & 0 & 18.00 & 41.20 & 64.40 & 81.30 \\
\hline cottonseed meal & 0 & 17.70 & 20.40 & 17.10 & 13.80 & 11.30 \\
\hline bone meal & 1.44 & 0.75 & 0.34 & 0.24 & 0.16 & 0.06 \\
\hline stone meal & 0.27 & 0.46 & 0.79 & 0.97 & 1.16 & 2.00 \\
\hline salt & 0.40 & 0.40 & 0.40 & 0.40 & 0.40 & 0.40 \\
\hline Premix $^{1}$ & 0.10 & 0.10 & 0.10 & 0.10 & 0.10 & 0.10 \\
\hline lucerne meal & 5.00 & 5.00 & 5.00 & 5.00 & 5.00 & 5.00 \\
\hline straw meal & 89.90 & 75.00 & 55.00 & 35.00 & 15.00 & 0 \\
\hline urea & 2.95 & 0.65 & 0 & 0 & 0 & 0 \\
\hline molasses & 1.00 & 1.00 & 1.00 & 1.00 & 1.00 & 1.00 \\
\hline vegetable oil & 1.00 & 1.00 & 1.00 & 1.00 & 1.00 & 1.00 \\
\hline \multicolumn{7}{|l|}{ Chemical composition, $\%$} \\
\hline $\mathrm{CP}$ & 13.60 & 14.20 & 13.54 & 13.05 & 12.96 & 14.43 \\
\hline NDF & 61.58 & 57.57 & 49.69 & 38.29 & 28.37 & 19.86 \\
\hline $\mathrm{ADF}$ & 42.42 & 39.63 & 31.14 & 12.98 & 8.89 & 5.75 \\
\hline $\mathrm{Ca}$ & 0.81 & 0.82 & 0.79 & 0.83 & 0.82 & 0.79 \\
\hline $\mathrm{P}$ & 0.35 & 0.34 & 0.37 & 0.38 & 0.34 & 0.36 \\
\hline
\end{tabular}

${ }_{1}^{1}$ per kg contain, IU: vit. A 3000, vit. $\mathrm{D}_{3}$ 1200, vit. E 10; mg: Cu 8, Fe 50, Zn 30, Mn 40, Co 0.1, Se 0.2 , I 0.5

\section{RESULTS AND DISCUSSION}

The results of digestibilities are presented in Table 2. Increasing dietary concentrate level resulted in an increase (linearly, $\mathrm{P}=0.001$ ) in the digestilities of $\mathrm{DM}$ and OM. This observation is in agreement with other study. The increased digestibilities of DM and OM seemed to be related to the concentrate had higher digestibility than roughage. With increasing the dietary concentrate level, there was a decrease in digestibilities of NDF and ADF $(\mathrm{P}=0.001)$. From the 
concentrate level range from 0 to $60 \%$, the digestibility of NDF and ADF did not significantly vary; while when the concentrate level was higher than $60 \%$, there was a significantly decrease in digestibility of NDF and ADF. The reduced digestibilities of NDF and ADF obtained from this study may be related to the lower $\mathrm{pH}$ (6.0-6.1), which may strongly inhibit activities of ruminal cellulolytic bacteria at higher concentrate level as stated by Calsamiglia et al. (2002).

Table 2. Effect of dietary concentrate level on the true digestibilities of DM, OM, NDF and ADF in continuous culture fermenters

\begin{tabular}{|c|c|c|c|c|c|c|c|c|c|}
\hline \multirow{2}{*}{ Item } & \multicolumn{6}{|c|}{ Dietary concentrate level, \% } & \multirow{2}{*}{ SEM } & \multicolumn{2}{|c|}{$\mathrm{P}<$} \\
\hline & 0 & 20 & 40 & 60 & 80 & 100 & & $\mathrm{~L}^{\mathrm{a}}$ & $\mathrm{Q}^{\mathrm{b}}$ \\
\hline \multicolumn{10}{|c|}{$\overline{\text { Digestibility, } \%}$} \\
\hline DM & $44.86^{\mathrm{d}}$ & $54.44^{\mathrm{c}}$ & $57.09^{c}$ & $60.72^{\mathrm{c}}$ & $69.38^{\mathrm{b}}$ & $77.22^{\mathrm{a}}$ & 2.345 & 0.001 & 0.484 \\
\hline $\mathrm{OM}$ & $47.76^{\mathrm{d}}$ & $57.08^{c}$ & $58.94^{\mathrm{c}}$ & $63.33^{\mathrm{c}}$ & $71.85^{\mathrm{b}}$ & $81.66^{\mathrm{a}}$ & 2.498 & 0.001 & 0.221 \\
\hline NDF & $41.08^{\mathrm{a}}$ & $47.26^{\mathrm{a}}$ & $43.85^{\mathrm{a}}$ & $41.56^{\mathrm{a}}$ & $31.25^{\mathrm{b}}$ & $18.75^{\mathrm{c}}$ & 1.838 & 0.001 & 0.001 \\
\hline $\mathrm{ADF}$ & $46.25^{\mathrm{a}}$ & $54.18^{\mathrm{a}}$ & $51.27^{\mathrm{a}}$ & $48.25^{\mathrm{a}}$ & $32.45^{\mathrm{b}}$ & $23.25^{\mathrm{b}}$ & 3.263 & 0.001 & 0.001 \\
\hline
\end{tabular}

a - linear effect of concentrate level; $b$ - quadratic effect of concentrate level

The microbial fermentation parameters are listed in Table 3. As dietary concentrate level increased, the $\mathrm{pH}$ of fermentation contents decreased. In this study, increasing dietary concentrate level resulted in increased growth of rumen

Table 3. Effect of dietary concentrate level on ruminal $\mathrm{pH}$, concentrations of ammonia and VFA in continuous culture

\begin{tabular}{|c|c|c|c|c|c|c|c|c|c|}
\hline \multirow{2}{*}{ Item } & \multicolumn{6}{|c|}{ Dietary concentrate level , \% } & \multirow{2}{*}{ SEM } & \multicolumn{2}{|c|}{$\mathrm{P}<$} \\
\hline & 0 & 20 & 40 & 60 & 80 & 100 & & $\mathrm{~L}^{\mathrm{a}}$ & $\mathrm{Q}^{\mathrm{b}}$ \\
\hline$\overline{\mathrm{pH}}$ & $6.69^{a}$ & $6.60^{\mathrm{ab}}$ & $6.42^{\mathrm{b}}$ & $6.13^{\mathrm{c}}$ & $5.82^{\mathrm{d}}$ & $5.52^{\mathrm{e}}$ & 0.067 & 0.001 & 0.022 \\
\hline $\mathrm{NH}_{3}, \mathrm{mg} / \mathrm{dl}$ & $42.21^{\mathrm{a}}$ & $38.89^{\mathrm{a}}$ & $29.54^{\mathrm{b}}$ & $16.35^{\mathrm{c}}$ & $12.59^{\mathrm{c}}$ & $5.26^{\mathrm{d}}$ & 1.518 & 0.001 & 0.902 \\
\hline \multicolumn{10}{|l|}{ Total VFA } \\
\hline $\mathrm{mMol} / 1$ & $48.96^{\mathrm{cb}}$ & $76.20^{\mathrm{b}}$ & $81.36^{\mathrm{ab}}$ & $83.65^{\mathrm{ab}}$ & $93.36^{\mathrm{a}}$ & $81.98^{\mathrm{ab}}$ & 3.647 & 0.001 & 0.001 \\
\hline $\mathrm{mMol} / \mathrm{d}$ & $172.2^{\mathrm{b}}$ & $261.3^{\mathrm{a}}$ & $287.7^{\mathrm{a}}$ & $308.3^{\mathrm{a}}$ & $331.2^{\mathrm{a}}$ & $302.7^{\mathrm{a}}$ & 17.49 & 0.001 & 0.002 \\
\hline \multicolumn{10}{|l|}{ VFA molar $\%$} \\
\hline acetate & $69.87^{\mathrm{a}}$ & $66.13^{\mathrm{b}}$ & $59.43^{\mathrm{c}}$ & $53.09^{d}$ & $51.38^{\mathrm{d}}$ & $53.83^{\mathrm{d}}$ & 1.278 & 0.001 & 0.001 \\
\hline propionate & $19.82^{\mathrm{d}}$ & $24.25^{\mathrm{cd}}$ & $30.05^{\mathrm{ab}}$ & $38.42^{\mathrm{a}}$ & $34.31^{\mathrm{ab}}$ & $28.12^{\mathrm{bc}}$ & 1.675 & 0.001 & 0.001 \\
\hline butyrate & $10.16^{\mathrm{b}}$ & $8.29^{\mathrm{bc}}$ & $8.36^{\mathrm{bc}}$ & $6.77^{\mathrm{c}}$ & $9.67^{b c}$ & $14.40^{\mathrm{a}}$ & 0.725 & 0.001 & 0.001 \\
\hline valerate & $0.15^{\mathrm{a}}$ & $0.33^{\mathrm{a}}$ & $1.00^{\mathrm{a}}$ & $1.08^{\mathrm{a}}$ & $2.90^{\mathrm{a}}$ & $2.61^{\mathrm{a}}$ & 1.098 & 0.053 & 0.862 \\
\hline iso-valerate & 0 & 0 & $1.64^{\mathrm{a}}$ & $0.64^{\mathrm{a}}$ & $1.74^{\mathrm{a}}$ & $1.35^{\mathrm{a}}$ & 0.995 & 0.205 & 0.655 \\
\hline
\end{tabular}

$\mathrm{a}$ - linear effect of concentrate level; $\mathrm{b}$ - quadratic effect of concentrate level

microbes fermenting NSC and in increased concentrations of organic acids. The optimal $\mathrm{pH}$ for ruminal fibre digestion has been reported to be between 6.7 and 
7.1; and fibre digestion normally is decreased when ruminal $\mathrm{pH}$ declines below 6.2. With increasing dietary concentrate level, ammonia concentration $(\mathrm{mg} / \mathrm{dl})$ decreased $(\mathrm{P}=0.001)$. Total ammonia in this study comes from the addition of buffer solution and dietary protein degradation. As concentrate level increased, the amount of ammonia used for microbial protein synthesis increased, thus the free ammonia concentration decreased.

Molar percentages of individual VFA were significantly $(\mathrm{P}=0.001)$ affected by dietary concentrate level. As dietary concentrate level increased, the percentage of acetate decreased $(\mathrm{P}=0.001)$, while the percentage of propionate and valerate increased $(\mathrm{P}=0.001)$. The increase in molar propionate proportion and the decrease in molar acetate proportion with increasing dietary concentrate level obtained from this study agreed with other study.

The data on microbial protein yield are presented in Table 4. Increasing dietary concentrate level significantly $(\mathrm{P}=0.001)$ enhanced daily microbial production (DMNP) and microbial growth efficiency (MOEFF; grams of microbial N/kg OM truly digested). The positive correlation of DMNP to the increasing dietary concentrate level was in agreement with other studies (Griswold et al., 2003).

Table 4. Effect of dietary concentrate level on microbial production and growth efficiency

\begin{tabular}{|c|c|c|c|c|c|c|c|c|c|}
\hline \multirow{2}{*}{ Item } & \multicolumn{6}{|c|}{ Concentrate level, $\%$} & \multirow{2}{*}{ - SEM } & \multicolumn{2}{|c|}{$\mathrm{P}<$} \\
\hline & 0 & 20 & 40 & 60 & 80 & 100 & & $\mathrm{~L}^{\mathrm{a}}$ & $\mathrm{Q}^{\mathrm{b}}$ \\
\hline $\mathrm{N}$ intake $\mathrm{g} / \mathrm{d}$ & 2.534 & 2.606 & 2.571 & 2.518 & 2.450 & 2.690 & 0.002 & - & - \\
\hline Dietary N & 1.741 & 1.829 & 1.733 & 1.659 & 1.633 & 1.847 & 0.001 & - & - \\
\hline Buffer N & 0.794 & 0.778 & 0.835 & 0.859 & 0.816 & 0.842 & 0.003 & - & - \\
\hline \multicolumn{10}{|l|}{ Effluent $N$} \\
\hline $\mathrm{NH}_{3} \mathrm{~N}, \mathrm{~g} / \mathrm{d}$ & 1.45 & 1.30 & 1.09 & 0.61 & 0.47 & 0.24 & 0.011 & 0.001 & 0.902 \\
\hline $\mathrm{NH}_{3} \mathrm{~N}, \mathrm{mg} / \mathrm{dl}$ & 42.24 & 38.89 & 29.54 & 16.53 & 12.59 & 5.26 & 1.101 & 0.001 & 0.902 \\
\hline $\mathrm{NAN}^{\mathrm{c}}, \mathrm{g} / \mathrm{d}$ & $1.090^{\mathrm{d}}$ & $1.312^{\mathrm{c}}$ & $1.480^{\mathrm{b}}$ & $1.910^{\mathrm{a}}$ & $1.978^{\mathrm{a}}$ & $1.461^{\mathrm{b}}$ & 0.011 & 0.001 & 0.902 \\
\hline $\operatorname{DMNP}^{\mathrm{d}}(\mathrm{g} / \mathrm{d})$ & $0.711^{\mathrm{c}}$ & $1.123^{\mathrm{b}}$ & $1.115^{\mathrm{b}}$ & $1.318^{\mathrm{b}}$ & $1.642^{\mathrm{a}}$ & $1.053^{\mathrm{b}}$ & 0.08 & 0.001 & 0.458 \\
\hline $\mathrm{NANMN}^{\mathrm{e}} \mathrm{g} / \mathrm{d}$ & $0.379^{\mathrm{ab}}$ & $0.189^{c}$ & $0.365^{\mathrm{bc}}$ & $0.592^{\mathrm{a}}$ & $0.336^{\mathrm{bc}}$ & $0.408^{\mathrm{a}}$ & 0.06 & 0.222 & 0.607 \\
\hline MOEFF $^{\mathrm{f}}$ & $23.06^{\mathrm{c}}$ & $30.54^{\mathrm{ab}}$ & $25.34^{\mathrm{bc}}$ & $30.18^{\mathrm{ab}}$ & $32.86^{\mathrm{a}}$ & $16.86^{\mathrm{d}}$ & 1.794 & 0.001 & 0.589 \\
\hline
\end{tabular}

Rumen microbial growth requires both energy derived from ruminal fermentation and ammonia. In this study, ammonia concentration being more than $5 \mathrm{mg} / 100 \mathrm{ml}$ seemed to be not a factor limiting maximum microbial synthesis as discussed above. Some researchers indicated that the main source of ATP and the most important determinant for microbial protein synthesis is carbohydrate fermented in the rumen. As dietary concentrate level increased, the energy for microbial growth simultaneously increased, resulting in an increased MNP and MOEFF. 
When concentrate level was higher than $80 \%$, however, the more fermentation products, such as VFA and lactic acid, lowered ruminal pH quickly $(<6.1)$, which inhibited the growth of cellulolytic bacteria and also limited the ruminal digestion of NDF and ADF (Table 2). Therefore, as dietary concentrate level increased, although microbial protein production and MOEFF were increased, their highest values seemed to be achieved in the dietary concentrate range from 60 to $80 \%$, rather than at $100 \%$ dietary concentrate level.

\section{REFERENCES}

AOAC, 1984. Association of Official Analytical Chemists, Official Methods Analysis. 12th Edition. Arlington, VA

Broderick G.A., Kang J.H., 1980. Automated simultaneous determination of ammonia and amino acids in ruminal fluids and in vitro media. J. Dairy Sci. 33, 64-75

Calsamiglia S., Ferret A., Devant M., 2002. Effects of $\mathrm{pH}$ and $\mathrm{pH}$ fluctuations on microbial fermentation and nutrient flow from a dual-flow continuous culture system. J. Dairy Sci. 85, 574-579

Chamberlain D.G., Thomas P.C., 1979. Ruminal nitrogen metabolism and the passage of amino acids to the duodenum in sheep receiving diets containing hay and concentrates in various proportions. J. Sci. Food Agr. 30, 677-686

Crawford Jr. R.J., Hoover W.H., Junkins L.L., 1980. Effects of solids and liquid flows on fermentation in continuous cultures. II. Nitrogen partition and efficiency of microbial synthesis. J. Anim. Sci. 51, 986-995

Grigsby K.N., Kerley M.S., Weigel J.C., 1993. Combination of starch and digestion fiber in supplements for steers consuming a low-quality bromegrass hay diet. J. Anim. Sci. 71, 10571064

Griswold K.E., Apgar G.A., Bouton J.J., Firkins L., 2003. Effects of urea infusion and ruminal degradable protein concentration on microbial growth, digestibility, and fermentation in continuous culture. J. Anim. Sci. 81, 329-336

Meng Q., Kerley M.S., Ludden P.A., Belyea R.L., 1999. Fermentation substrate and dilution rate interact to affect microbial growth and efficiency. J. Anim. Sci. 77, 206-214

Stern M.D., Hoover W.H., 1990. The dual flow continuous culture system. In: Continuous Culture Fermenters: Frustration of Fermentation. North Eastern ADSA-ASAS Regional Meeting, W. H. Miner Agricultural Research Institute, Chazy, NY

Van Soest P.J., Robertson J.B., Lewis B.A., 1991. Methods for dietary fiber, neutral detergent fiber, and nonstrach polysaccharides in relation to animal nutrition. J. Dairy. Sci. 71, 737-744

Zinn R.A., Owens F.N., 1986. A rapid procedure for purine measurement and its use for estimating net ruminal protein synthesis. Can. J. Anim. Sci. 66, 157-166 